\title{
12
}

\section{Conflicts in marginal locations: Small-scale gold-mining in the Amazon}

\section{Marjo de Theije and Ton Salman}

Researchers of the GOMIAM consortium ${ }^{1}$ have worked on conflicts surrounding small-scale gold-mining in the Amazon since 2010. We understand conflict in a broad sense and have studied many different forms of it, ranging from armed conflict and environmental conflict, to conflicts of interest between local populations and migrant miners, between large-scale mining and small-scale mining, between local, regional and national governments on issues of small-scale mining, and even between small-scale miners and other small-scale miners, like between equipment owners and operators. GOMIAM researchers work in Bolivia, Brazil, Colombia, French Guiana, Peru and Suriname.

All the various types of conflicts we mentioned have increased dramatically because of the tremendous growth of small-scale gold-mining, but are also seen in medium- and large-scale gold-mining. Environmental issues are among the most prominent causes of conflict. The environmental threats connected to gold-mining include deforestation and air and water pollution from cyanide and mercury contamination. Polluting effects

1 GOMIAM is a comprehensive research project on small-scale gold-mining and social conflict in the Amazon region, comparing states, environments, local populations and miners in Bolivia, Brazil, Colombia, Peru and Suriname. See www.gomiam.org. 
of small-scale gold-mining often threaten the livelihoods of indigenous peoples or peasants in the vicinity of the mining operations. Small-scale mining activities are often relatively low-tech, organised with informal labour and family networks and, although limited in geographical scale, are still very harmful because of the uncontrolled expansion of (albeit often small) operation sites, and because of the frequent careless use of mercury and other chemicals, with little awareness about the effects of inorganic waste.

Not only does the environment cause conflicts, the land does too. Land conflicts between miners and other collective or private concession holders or local inhabitants, like indigenous communities, peasants, loggers, Amazon nut-collectors or those involved in other forest extraction activities, abound. Quite often, due to deficiencies of government institutions, overlapping concessions are given out to various local players, like miners, agro-business or eco-tourism entrepreneurs, and indigenous communities. Conflicts between the various state ministries responsible for these contradictory policies are often minor in comparison to the conflicts that erupt on the ground because of what was granted to such players.

Such effects obviously bring up critical questions about concessions given out by national or local authorities, about the lack of effective control and protection for the local population, in case the concessions were not officially granted, or if the miners or mining companies do not respect the conditions that were attached to it.

These are only some of the fields of conflict to be found. In our analysis of the gold conflicts, we have found many similarities between the countries studied. Next to the elements we mentioned above, there are many other parallels; for instance, in all countries the state makes efforts to control or profit from the gold-mining, usually initiating processes of 'formalisation' that include licensing, taxation and environmental requirements. The success of such efforts varies. In all countries, local people and migrants compete and/or collaborate in artisanal and small-scale mining (ASM), making a living from it in situations where they often have very few alternatives. Also, everywhere, small-scale gold-mining is associated with negative qualifications of illegality, criminality, prostitution and violence. The reactions researchers get when announcing a visit to the mining areas are always full of warnings and calls to be careful. In the imagination of many, small-scale gold-mining is full of corruption, vigilantism, an eye for an eye and a tooth for a tooth. Finally, and in spite of much heterogeneity 
in this regard, we found that it is not anarchy or sheer ad hocism that rules in the mining areas. Everywhere there is some form of association, organisation and rules.

Our analyses of the conflicts have focused on different forms of legal systems (Theije et al. 2014), on formalisation and inefficient state capacity (Damonte Valencia 2013; Heemskerk et al. 2015), on migration (Theije and Heemskerk 2009), on organisation of miners (Carrillo et al. 2013) and more. However, the conflicts are complex and multilayered, and we need theoretical tools that might help to unpack and analyse the nature, layers, time frames and possible ways forward to address these conflicts. Elsewhere, (Salman and Theije 2017) we have suggested a multitemporal model to understand the structural backgrounds, the actors' dispositions and capacities, and the strategic and tactical manoeuvring of different stakeholders in conflicts. Here, we focus on a feature of another nature: the spatial characteristics of most gold-mining operations.

In this chapter, we will take a small step in the development of such a framework by attempting to shed light on one specific characteristic of mining that became apparent in all our case studies_in all countries, the mining takes place in remote parts, distant from urban centres, distant from regulating state apparatuses, distant from services and legal markets. What is the role of this physical distance, this far away situation and this isolation from urban centres in the conflicts surrounding mining, and how can our attention on this fact lead to insights that might contribute to a more thorough understanding and possibly to a solution for the conflicts?

We therefore explore the multilayered nature of conflict using the notion of marginal territory, to shed light on some of the most notable features of conflict and the processes underlying the conflicts in the small-scale gold-mining in the Amazon. The location and marginality of the mining regions is part of the structural dimension of the conflicts related to small-scale gold-mining. What is the role for the actual interactions and encounters, the confrontations between actors in the field and the choices people make to join in, be part of the conflict, or stay out?

We will distinguish four different takes on the remote, isolated, faraway situation of many of the small-scale gold-mining operations in the Amazon, and discuss each of these on the basis of a short case. Based on 
the results, we come to some general conclusions about the role of geographical and political distance as a structural feature in the conflicts around gold-mining.

\section{Mining in marginal territory (outside state control)}

The mining activities we study usually take place in remote parts of nation states, in the dense and often difficult to access remote areas in the tropical rainforest. The physical and organisational distance from state control affects conflicts between state representatives and groups of the population, and miners who have different accesses to state backing and authorisation. Remoteness means that activities take place in areas that are marginal from the perspective of the political and economic centres of that region of the country. For the parties involved, it means exclusion from locations of decision-making, as well as a lack of representation and presence in public spheres.

A good case in point is the Peruvian region of Madre de Dios, which is the scene of an enduring dispute between small-scale miners and the authorities. In part, the dispute can be explained by knowledge hiatuses, miscommunication and refusal to understand the other party's interests. Damonte (2016) explains how the Peruvian Government attempted to formalise small-scale mining as a measure in a larger plan to counter the environmental impact of illegal mining. The formalisation, however, included declaring all small-scale mining in the protected non-mining zone areas as illegal, thus creating more illegality. From the perspective of the miners, this was a threat to their livelihoods and a violation of agreements they had about the use of the land. So far, no workable solution has been found to resolve the conflicting understandings of the situation.

The central government in Lima is not really interested in the miners, or in the region, and gives no priority to combating illegal small-scale mining. But at the same time, the government is whimsical in this respect. Pressure to intervene comes from the international community and Peru's own (weak and inefficient) environmental department. The benefits of the small-scale mining in economic terms are marginal for the state, as it makes no significant contribution to Peru's gross domestic product. What remains is that for the Peruvian state, the formalisation process 
is a governance instrument for a remote region that it still is unable to govern. ${ }^{2}$ The central government fails to acknowledge the complex social dynamics that rule the remote Amazonian region.

Historically, the Peruvian state followed a 'conquest' approach that solely focused on extraction of resources from the region. In Madre de Dios, the state never developed a program of social and economic development. As a consequence, the state can hardly 'read' contemporary local society (Damonte 2016) and resorts to punitive actions against the miners on an ad hoc basis, most often without success. The central government has proved incapable of collaborating with regional authorities, for whom the small-scale miners represent an economically important factor, and a politically dominated area. As a result, the miners refuse to collaborate, and instead contest, delay and sabotage the government's plans to reorganise their mining activities. The authorities are insufficiently equipped to enforce the law, because they are unable to grasp the complex societal dynamics underlying small-scale mining. Specifically, the failure of the state to integrate local people and local agendas in the process of formalisation hinders current attempts to intervene with any real effect. For the state, operating 'from Lima', Madre de Dios continues to be a marginal, unknown and unruly area.

\section{Mining in marginal territory (delegated state control)}

The small-scale miners in Peru worked and organised the territory in the absence of the state for a long time. Now that the state wants to interfere, they ignore, resist and subvert the actions of the state. This also happens in other parts of the Amazon. Others may step into the void to 'represent' the state or assume the tasks it is unable to fulfil. Who are the actors that can do that, and what are the means they apply to do so?

2 Damonte refers to Foucault's (2009) discussion of the concepts of sovereignty and governmentality, as the different and successive ways states can establish governance. A state achieves territorial sovereignty when it is capable of controlling the territory through territorial knowledge (territorial data) and administrative power. 'Governmentality' refers to the 'institutions, procedures ... that allow the exercise of ... power that has the population as its target' (Foucault 2009: 108), and to the government apparatuses and related knowledge used to govern the population that lives in its sovereign territory. 
To elucidate this question, Suriname offers a good example. Suriname is a small country in the northeastern part of the Amazon, which witnessed a substantial increase in small-scale gold-mining activities in the 1990s. The gold-bearing lands are located in the sparsely populated interior, where only Maroons and Amerindians live. In this part of the country, the state has historically been completely absent, and still there are hardly any services provided to the people: no schools, no health services and no police, to name just some basics. The local inhabitants were totally overlooked when mining began to develop. The government issued several large concession areas for prospecting to some businessmen and to the national mining company. In and around these 'official' concessions, the local tribal people in whose traditional territory the concessions were located also started mining more actively than they had done in previous decades. But land rights of the tribal people are not recognised in Suriname, and the rights to mine were never assigned to them either. This resulted in colliding claims and overlapping operations.

In 1991, two concessions were issued to people from the capital, Paramaribo, at the Lawa River-traditional territory of the Aluku (or Boni) Maroons and Wayana indigenous peoples. For the indigenous people, the new concession holders, with official documents in their hands, were complete strangers, even aliens - as if Columbus had landed again on the (allegedly uninhabited) territory of the continent and, without even blinking, declared, 'In the name of the King of Spain I take possession of this land and everything that belongs to it ...'. Now, new territorial names and rights were created. The Antino concession came into the hands of Nana Resources, a family company of the Naarendorps; the Benzdorp concession went to Grassalco, the state business company. The two concessions each comprise about 140,000 hectares. Although, strictly speaking, the rights conferred to these outsiders were exploration rights and not exploitation rights, the companies soon started to effectively mine on the concessions. They did so by inviting others - migrant miners and local Maroons. Instead of initiating operations themselves, they gave access to migrant small-scale miners, most of them Brazilians, with a lot of knowledge and experience as small-scale gold miners (usually called garimpeiros), who brought their own equipment and paid 10 per cent of the production to the concession holders.

Subletting is prohibited in the national mining law, but in the miners' culture it is an accepted rule that the 'owner of the mining land' has the right to collect a percentage of the gold. For the Brazilian garimpeiros, this 
was a known practice. However, the indigenous Aluku and the Wayana felt that this completely ignored and overruled their (customary) rights and they resisted complying with these rules, which were now claimed and implemented by the new 'owners of the land'. In this struggle, the state remained absent on the ground. In Paramaribo, a minister or another official would occasionally explain on television that all mineral resources belong to the nation, suggesting that these firms (having their base in the city of Paramaribo) were representing the state and operating on the basis of its ruling and, therefore, had more right to mine than local inhabitants or migrants, who in actual fact were doing all the hard work. This was all in the midst of internal frictions between the garimpeiros and the Maroons, and with the 'rights dispute' remaining a moot point.

The situation became even more complex when the two firms that were the concession holders started negotiating with 'big fish' from elsewhere: Canada- and USA-based junior companies; exploration companies looking for gold deposits that have potential for large-scale exploitation; and large-scale mining companies. The two firms, Nana Resources and Grassalco, acted as gatekeepers and facilitators. They had probably taken on the concessions because they hoped to attract foreign investors, who would have the knowledge and capital to undertake serious prospecting, and would eventually build and exploit large-scale mines on their concessions. In the early 1990s, such companies initiated professional exploration activities: Golden Star at the Antino concession, and Canarc at the Grassalco concession. In both cases, it did not result in large-scale exploitation projects. The gold reserves were not big enough to justify the scale of investment that would be necessary. It was unlikely that costs and yields would bring a beneficial outcome.

Whereas the local gold miners- the Maroons-refused to pay 10 per cent of the produce to the concession holders, the migrant miners adapted to the rules set by the firms. The small-scale miners were allowed to work wherever they wanted on the large concessions. They had to prospect for themselves, and could then talk to the 'security man' of the firm to obtain permission for opening a mine on the location of their choice. Doing so in large numbers, the garimpeiros became the prospectors for the international firm, while they also paid 10 per cent of their raw production to Nana Resources (Theije and Bal 2010). The concession owners collected kilograms of gold every week. In the heydays of the Antino concession, at the beginning of 2006, more than 60 small-scale mining operations were producing gold. Although later, the number of 
producing miners went down-amongst other reasons, because they were sent away when Nana Resources eventually started a mining operation on part of the concession-the subletting system continues to be an important part of the local organisation of the mining business.

So in the absence of, or under ineffective control by, state representatives, gold production is completely managed according to the rules set by the concession owners. On the margins of Suriname society, far away from the central state, but deriving authority from this same centre, delegated through the concession system, the concession owners use this authority to guarantee and monopolise for themselves, and subsequently distribute to others, the access to profits (Ribot and Peluso 2003) from the goldmining activities. Their power, however, has not been effective enough to make the Maroons obey.

\section{Marginal territory creates local control}

In the absence of central authority, or in the presence of ineffective authority, conflict resolution and organisation at the mining sites is often self-administered and self-regulated. The self-administration is, of course, more flexible than bureaucracies or other institutionalised forces imposing the rules. But it often comes at the cost of imbalances in terms of abilities to promote one's interests. Yet, there is a common interest in security about the ways to act, to obey and to comply. Even in makeshift circumstances, in temporary mining camps, in continuously changing working settings, total improvisation or 'making it up as you go' will not last long; people will get together and arrange a system, no matter how precarious, unjust or violent it may be, to channel things. Total anarchy and unpredictability is bad news for all players, whatever their working and living configurations. We will return to this point later.

Where the state has no control, others take over. Some will often monopolise the use of violence and control over people's moves and work. In the Suriname case just described, the 'security' employees of the concession holders most often assume the role of police, even when it concerns persons and issues not related to the firm and mining on the concession. So when there is a fight in the neighbouring settlement, they are the ones that will go there to settle issues, administer justice and restore peace, sometimes even keep perpetrators captive for a short time, or some days, before handing them over to the national police officers who 
are called from town. The miners also appeal to them to settle quarrels between spouses, or to ask help with disagreements regarding payments between miners.

In other parts of the Amazon, the hosts to the migrant miners may also take on the role of local authority and control the conflict and violence. In Brazil, this is commonly the 'owner of the mine', who usually is the person who first found gold in the location and therefore obtained the right to ownership in the mining culture. Although the 'owner of the mine' eventually may have (partly) formalised his access to the gold, usually his power extends to other arenas of social life in the mine. 'Inside' is a world in itself, where gold-mining defines activities, identities and rules (Larreta 2002: 45). Inside, the negative qualifications of small-scale gold miners that are prevalent 'outside' are absent. Inside is also where the marginality of the territory gives way to the authority of the owner of the mine, who not only safeguards his access to the gold, but also decides on other issues in the garimpo, the mining site, such as resolving conflicts between workers.

In quite a similar way, the inhabitants of the Grankriki region in Suriname control the Brazilian migrant miners' access to the mining grounds-not only to mine, but also to live there. They are miners themselves, and work closely together with the Brazilians. The Brazilians refer to the local Maroons as concession owners, although they have never obtained mining concessions from the competent state authorities. The situation here is that the concession was given to a company that does not use its right to explore the area for gold findings and, unlike the firms described above, also did not set up any infrastructure to control the exploration and exploitation of others. As a result, the Maroons of the area have turned their lands meant for planting and hunting into mining 'concessions' too. The families from the villages each have a specific part of the area as their claim, where they mine themselves and give access to migrant miners to mine as well. The migrant miners pay a part of the gold production, usually 10 per cent, to the family on whose 'concession' they work.

The 'concessions' are small and pass from the family elders to the younger men, who then take care of the social and economic organisation. They collect the contributions from the miners, and keep peace and order-for which they are highly respected by the garimpeiros. If there are fights, they simply send the troublemakers away. And because access to the gold is what brings the people here together in the first place, being sent away is a serious punishment. In this situation, the local control of the mining area works well. 


\section{Mining 'claiming' claims in the margin}

Now, we come to the fourth instance where mining-related conflicts and marginal territory interact with each other. This time, we see the connection the other way around: the marginal territories are also in a way created by the mining activity. They are constituted, constructed and built in reaction to the mining operations that go on there. In other words, we have to look at the way in which mining activities are constitutive for territorial organisation and claims, hence the 'situatedness' of mining regions, which in turn lie at the base of conflicts.

The goldfields in the south of Suriname continue at the other side of the border (which is the Lawa River) into French Guiana. Goldfields do not respect national borders. For the Aluku Maroons and Wayana Amerindians as well, the region is one continuous territory where they have lived for many decades, and even centuries. The local population moves, lives and travels in the territory on both sides of the river and national border, to plant their gardens, build their houses and search for hunting and fishing areas. They also freely use both sides of the river to gain direct access to the gold, and to try and control the access of others to it. So when it became too difficult to mine on the French side, where the state has a stronger presence as compared to Suriname, some Aluku moved to the Suriname border of the Lawa River to mine. Although they may not have set foot there for years, now that they had become miners, the territory turned interesting again and they claimed it as tribal territory without further ado. The concession holders would obviously not acknowledge or respect any such claim based on traditional settlement, but the migrant miners, other Aluku and the members of indigenous groups and other Maroons in the region were willing to admit such entitlements. The status of a region and one's right to live, work or mine there hence proves to depend on different parameters for different local groups or actors. 'Legitimately mining' somewhere, or defining an area as 'justifiably accessible' for someone, depends on whom, and with what imposition of power, responds to such claims.

The local inhabitants also found other ways of making a living from the gold rush and, here too, they in a way created the nature, 'identity' and (indirect) accessibility of a disputed mining region. Along the Suriname border of the Lawa River, settlements of mechanics and equipment maintenance personnel, merchants, bar owners, sex workers, smugglers and temporarily unemployed miners and cooks have emerged since 2006. 
Some have as many as 50 houses, bars and shops, but several other smaller places have also emerged on the Suriname bank of the river. The Aluku and Wayana collect monthly payments from the migrants who have built houses and run their commercial businesses catering for the gold miners here. At these locations, the land that was unused and untouched before gold-mining became significant. It was 'community forest' without particular ownership claims or customary destinations for these locations. But now, due to the recent gold rush in the region, these marginal territories became important and, with that, they also emerged as sources for conflicts between local people, migrants and, from time to time, the state.

In assessing the importance and 'constituting force' of these settlements, we need to bring in the fact that French Guiana and Suriname have very different politics with respect to small-scale gold-mining. In comparison to the Suriname policy of laissez-faire, French Guiana actively tries to eradicate illegal small-scale gold-mining with a large police and military force. However, the French have little success with their policies because ASM is maintained and supplied from Suriname. Additionally, Suriname offers 'sanctuary' for those miners that need to flee from French law enforcement officers, having been caught illegally mining or bringing provisions. The newly occupied marginal territory generates opportunities for different actors here. Miners cross the borders easily and, most of the time, completely unnoticed. Miners find facilities close by and, at the same time, out of reach of the French. In turn, the Surinamese shop and workshop owners obtain a livelihood. This is only possible due to the marginal status of this territory.

\section{Conclusion: Gold conflicts in marginal territories}

Reflecting upon the role and importance of physical distance-of being only difficultly governable and being isolated from the key urban centresin the conflicts surrounding mining, we come across various important features.

What we can say is that a lack of effective state governance and authority characterises the marginal areas where much of the small-scale goldmining takes place. In our research in the Amazon, we found different effects when it came to the emergence and evolution of conflict. 
To begin with, we found that the idea that mining areas beyond the effective range of the state embody a complete mobocracy or ochlocracy, a full collapse of any system, mere lawlessness and complete explosion of violence seems to be untrue. Although possibly unjust, and partly based on physical power, some rule and some routine about how to interact, whom to pay and whom to obey exists. Different players, even in competition, benefit from some predictability, a certain acceptance of power and a certain acknowledgement of the other's position and legitimacy. We must add, however, that the territorial marginality may both contribute to the ineffectiveness of government in the mining areas, as well as be the result of local dynamics undermining and altering the state's definition of the region, and the state's proposal on how it should be administered.

Second, the focus on the marginal status of the mining regions shows that the lack of state control opens opportunities for other actors to usurp authority and embody legal and less-legal power. These actors are often from circles close to the state, and borrow the power of the state to impose themselves locally. They will, however, often need to make concessions because they cannot call in the full force of the state to enforce their will.

In other cases, however, we see that it is not the one closest to the state that prevails. The situation of marginality also opens opportunities for those who have no such proximity to the power structures of the state. These actors will often bring in their creative and innovative vehicles to promote their interests and obtain good results through their well-planned interactions with the other players. Their power or authority is based on other elements, such as geographic or technical knowledge, traditional or customary entitlements, or established rules and expectations.

In all cases, the total or partial absence of the state does not result in chaos or a blunt measure of physical strength. Violence, or the permanent threat of violence, benefits no one. One way or the other, the situation of not being governed will lead to some form of creative, albeit often unfair, and yet to some degree agreed-upon, self-governance.

To summarise, we note that in the marginal areas, the access to mining grounds is taking place in many different ways: sometimes triggering conflicts between actors involved, while in other situations leading to the formation of surprising collaborations. Where conflicts occur, they are intimately related to the state of marginality of the mining areas. 
Not rights or judicial force, but an independent dynamic of strengths and understanding interdependencies and interest balances seem to be the drivers that regulate conflicts. We can recommend that government interventions in such constellations always carefully take note of the situation on the ground if they do not want to do more harm than good.

\section{References}

Carrillo, F., T. Salman and C. Soruco, 2013. 'Cooperativas de Minería de Pequeña Escala en Bolivia: De Salvavidas de los Pobres a Maquinaria de Manipulación Política.' Letras Verdes. Revista Latinoamericana de Estudios Socioambientales 14: 235-54.

Damonte, G.H., 2016. "The "Blind" State: Government Quest for Formalization and Conflict with Small-Scale Miners in the Peruvian Amazon.' Antipode 78(4): 956-76. doi.org/10.1111/anti.12230

Damonte Valencia, G., 2013. 'Formalizing the Unknown. The Stalemate over Formalizing Small-Scale Mining in Madre de Dios.' The Broker: Connecting worlds of knowledge, 5 November. Available at www.thebrokeronline.eu/Articles/Formalizing-the-unknown

Foucault, M., 2009. Security, Territory, Population: Lectures at the Collegge de France 1977-1978. Vol. 4. Basingstoke, New York: Palgrave Macmillan.

Heemskerk, M., C. Duijves and M. Pinas, 2015. 'Interpersonal and Institutional Distrust as Disabling Factors in Natural Resources Management: Small-Scale Gold Miners and the Government in Suriname.' Society \& Natural Resources 28(2): 133-48. doi.org/10.1 080/08941920.2014.929769

Larreta, E.R., 2002. 'Gold is Illusion': The Garimpeiros of Tapajos Valley in the Brazilian Amazonia. Stockholm Studies in Social Anthropology. Stockholm: Department of Social Anthropology, Stockholm University.

Ribot, J.C. and N.L. Peluso, 2003. 'A Theory of Access.' Rural Sociology 68(2): 153-81. doi.org/10.1111/j.1549-0831.2003.tb00133.x 
Salman, T., and M. de Theije, 2017. 'Analysing Conflicts around SmallScale Gold Mining in the Amazon: The Contribution of a Multitemporal Model.' The Extractive Industries and Society 4(3): 586-94. doi.org/10.1016/j.exis.2017.03.007

Theije, M. de and E. Bal, 2010. 'Flexible Migrants. Brazilian Gold Miners and their Quest for Human Security in Surinam.' In E. Bal, T. Eriksen and O. Salemink (eds), A World of Insecurity: Anthropological Perspectives On Human Security. London/Virginia: Sterling/Pluto Press.

Theije, M. de and M. Heemskerk, 2009. 'Moving Frontiers in the Amazon: Brazilian Small-Scale Gold Miners in Suriname.' European Review of Latin American and Caribbean Studies 87: 5-25. doi.org/ 10.18352 /erlacs. 9600

Theije, M. de, J. Kolen, M. Heemskerk, C. Duijves, M. Sarmiento, A. Urán, I. Lozada, H. Ayala, J. Perea and A. Mathis, 2014. 'Engaging Legal Systems in Small-Scale Gold Mining Conflicts in Three South American Countries.' In M. Bavinck, L. Pellegrini and E. Mostert (eds), Conflict Over Natural Resources in the Global South-Conceptual Approaches. Abingdon, UK: CRC Press/Taylor \& Francis. doi.org/ 10.1201/b16498-9 
This text is taken from Between the Plough and the Pick: Informal, artisanal and small-scale mining in the contemporary world, edited by Kuntala Lahiri-Dutt, published 2018 by ANU Press, The Australian National University, Canberra, Australia.

doi.org/10.22459/BPP.03.2018.12 